\title{
Design of Electronic Elementary Material Learning Module on Vocational Higher Education
}

\author{
Ade Fitri Rahmadani ${ }^{1}$, Hendra Hidayat ${ }^{{ }^{*}}$, Eril Syahmaidi ${ }^{1}$ \\ ${ }^{1}$ Universitas Bung Hatta, Aie Pacah Road, Padang, Indonesia \\ *Corresponding Author: Hendra Hidayat
}

\begin{abstract}
:
This study aims to describe the design of a valid Learning Module for Elementary Elementary subjects. This research type is research of development by using 4D model that is definition stage (define), design stage (design), development stage (develop), and dissemination stage (disseminate). This study looks at whether the designed module is valid, then conducted expert test, namely expert design of Elementary Electronic Learning Module and expert readings Elementary Electronic Learning Module. Aspects that are tested to experts are aspects of the material in the learning module, aspects of presentation on learning modules and aspects of language and legibility. The results showed that the basic Electronic Elementary Learning Module by experts is valid. Then it can be concluded that the Module on Higher Education Vocation is valid.
\end{abstract}

Keywords: Design, Learning Module, Elektronika Basic, Valid.

\section{Introduction}

The purpose of Higher Education is to develop the potential of students to become human beings who believe and cautious to God Almighty and have a noble, healthy, knowledgeable, skilled, creative, independent, skilled, competent, and cultured for the benefit of the nation and produce graduates who master the branch Science and / or Technology to meet the national interest and increase the nation's competitiveness. Education in Higher Education is continuously doing development in the implementation system for the purpose of the Higher Education System is achieved. One of them is through the process of learning that is not just giving material, topics or strategic concepts, but also provides a learning experience that allows the development of student independence to learn. Factors that can develop students' independence to learn include the availability of learning resources in the form of textbooks, modules, duty sheets, dictates lectures, and others in accordance with student learning characteristics so that will bring the interest of students to learn independently.

Electronic Elementary Course is one of the Compulsory Courses that must be studied in Higher Education Vocational. Competencies to be achieved after studying this course are students able to master the basic concepts of electronics related to electronic components and able to apply them in a series and analyze it in accordance with the exact formula, able to explain, identify and determine the value of electronic components, and able to apply it in solving problems in everyday life. Achievement of the competence is supported by many factors one of them with the use of teaching materials that can be understood and understood by students according to the characteristics of users. Based on the observations and interviews of lecturers and students of Informatics and Computer Engineering Education Study Program, especially in Basic Elementary Subject subjects, it is found that generally students do not have enough textbooks for conducive learning process.

The basic lecture subject of Electronics in the textbook specified is not structured according to the curriculum made by the lecturer. The lecture material that will be taught is not all presented in textbook, so it takes some books to be used as supporting other lecture materials. In addition, the composition of the material to be taught is not in accordance with the existing arrangement of material on textbooks used. This irregularity causes material sustainability to be disturbed. This can certainly hamper the creation of a conducive lecture 
process. Presentation of material in elusive textbooks is also often complained of by students. From the experience of teaching Elementary Elementary subjects, it is known that students' difficulties in studying lecture materials in textbooks is that there is no complete explanation about the subject matter, and the guidance on practical work steps is not presented in detail and clear. As a result, students are just waiting for an explanation from the lecturer.

The technique of preparing the material on a textbook is incapable of engaging the student actively in practicing independently of the material he / she studies. The lack of involvement of students in building conceptual understanding resulted in the students easily forgetting about the material. In addition, students also find difficulties in applying the knowledge they acquire in various contexts. Based on the information it is concluded that the cause of the low learning outcome of one of them is the use of textbooks that have not been able to guide the students to be actively involved in conducting the practice independently in order to build an understanding of the concept. Textbooks are not equipped with clear training and workmanship instructions that have not been able to guide students to be independent in learning.

In an effort to improve motivation, activity and learning outcomes in the students of Informatics and Computer Engineering Education, selected alternative problem solving is by developing a teaching materials. Teaching materials is one learning resource that is used to facilitate the distribution of messages to be conveyed by lecturers to students. Teaching materials that want to be developed is a modular print material. Modules that will be developed researchers will be designed and packed with language that is easy to understand so as to generate motivation and curiosity of students in doing practicum. Based on the above description then held a research that aims to describe about the design of a valid Learning Module for Elementary Elementary courses.

\section{RESEARCH MethodS}

This study aims to develop a basic Electronic Module valid, practical, and effective in terms of content and constructs. The module development procedure uses the 4-D model proposed by Thiagarajan et al, in Trianto (2007: 65). This model consists of 4 stages, namely the definition stage (define), the design stage (design), the stage of development (develop), and dissemination stage (disseminate). Disseminate stages are not done due to time constraints then only in the development stage only. In this study only 3 stages, namely definition stage, design stage, and development stage. The complete research design can be described in the following procedure.

\subsection{Definition Stage (define)}

This stage is done to see the description of conditions in the field related to the teaching and learning process of Basic Electronics in Higher Education Vocational, then analyze the problems. The process is done as follows.

a. Analyze the syllabus that aims to find out whether the material taught is in accordance with the competency standards and basic competencies of the course.

b. Analyze Elementary Textbooks, to see the appropriateness of the contents of the book with the standard of competence and basic competencies that must be achieved by the students. The appropriate books will be used as a reference for the preparation of concepts and examples of problems and exercises on the modules to be developed.

c. Review the literature related to module development.

d. Studying the characteristics of students to facilitate the level of language in the module and the difficulty of the problem.

e. Interviews with colleagues and students aimed at identifying any problems / obstacles encountered in the field in relation to Basic Electronics courses.

\subsection{Design Phase (design)}

The results of the defining stage are used at the design stage. At this stage, the action to be taken is to design the Electronic Elementary module.

The module contains course descriptions, subject matter, examples, guided exercises and bibliography. The presentation of module material can be done in several meetings that have been adapted to the syllabus

\subsection{Development Stage (develop)}

At this stage the actions taken are to validate, test the practicality and effectiveness of Electronic Elementary modules. Validation is done by the material experts who master the field of competence learned and media experts who master the field of learning media or multimedia. Material experts or media experts can be from the lecturers who mastered each of these areas or have a long teaching 
experience. This validation aims to determine the eligibility of lecturing modules that have been developed. If the validation result turns out that the module is invalid then the module needs to be fixed / revised so that it becomes valid. There are 2 kinds of validation used in this module, as follows:

1) Content validity, ie whether the module has been designed in accordance with the course syllabus.

2) The validity of the construct, ie the suitability of the module components with predetermined indicators.

The validated aspects can be seen in Table 1 .

Table 1: Module Validation

\begin{tabular}{clll}
\hline No & Aspect & $\begin{array}{l}\text { Method of } \\
\text { collecting data }\end{array}$ & Instrument \\
\cline { 1 - 2 } 1. & $\begin{array}{l}\text { Material in } \\
\text { Module }\end{array}$ & $\begin{array}{l}\text { Gave a } \\
\text { validation sheet }\end{array}$ & $\begin{array}{l}\text { The } \\
\text { validation } \\
\text { sheet }\end{array}$ \\
\cline { 1 - 2 } 2. & Presentation & to an & \\
\cline { 1 - 2 } 3 & $\begin{array}{l}\text { Language } \\
\text { and }\end{array}$ & Elementary & Electronics \\
& legibility & expert, an & \\
& & $\begin{array}{l}\text { Education } \\
\text { Technology }\end{array}$ & \\
& & specialist and a & \\
& & language \\
& & \\
& &
\end{tabular}

The validation sheet is used to determine whether the module and the instrument that has been designed is valid or not. Data obtained through various instruments were analyzed qualitatively and quantitatively. Data from the result of module validation sheet, sheets of pratikalitas, and test of learning result were analyzed quantitatively, then used descriptive technique to draw qualitative inference. Data analysis techniques of each instrument are described as follows:

Validation results from validator to all aspects assessed, presented in tabular form. Next sought the average score by using the formula (Muliyardi, 2006: 82):

$$
R=\frac{\sum_{i=1}^{n} V_{i}}{n}
$$

$\mathrm{R}=$ the average result of the validator's assessment

$\mathrm{Vi}=$ the score of the $\mathrm{i}$-validator's appraisal result $\mathrm{n}=$ many validators

Then the mean earned is confirmed by the specified criteria. How to get the criteria are as follows:

a. Span of scores ranging from 0 to 4 b. Criteria is divided into five levels. The term used is adapted to the respective aspects.

c. The average span is divided into five interval classes.

Then calculated the average of all aspects for the module. To determine the level of validity and Module used the following criteria:

a. If the average> 3.20 then Module is categorized very valid.

b. If $2.40<$ average $\leq 3.20$ then the Module is categorized as valid.

c. If $1.60<$ mean $\leq 2.40$ then Module is categorized quite valid.

d. If $0.80<$ average $\leq 1.60$ then Module categorized less valid.

e. If the mean $\leq 0.80$ then the Module is categorized as invalid

\section{Results AND Discussion}

The development of the Basic Electronics module using the 4-D model has the following results.

\section{Module Validity}

To obtain a valid module, performed several stages in accordance with the 4-D model proposed in the research method. The results obtained at each stage can be described as follows.

\subsection{Define}

This stage is done to see the description of conditions in the field related to the lecturing process of Elektronika in vocational higher education. At this stage steps such as syllabus analysis, textbook analysis, literature analysis, characteristic analysis of students and interviews with peers. The results obtained in each of these steps are as follows.

\section{1) Analysis of Syllabus}

At this stage an analysis of the syllabus of Elementary Electronics subjects in vocational higher education. The syllabus analysis is done to see if the material taught is in accordance with the expected competence. Based on the result of the syllabus analysis, it is known that the Competency Standard (SK) of this course is the student able to master the basic concept of electronics related to the electronic component and able to apply it in a series and analyze it according to the exact formula, able to explain, identify and determine the value of components of electronics, and able to apply it in solving problems in everyday life.

Based on the results of syllabus analysis, the module in Basic Elektronika lecture was developed for basic materials of Electronics namely basic 
concept of electronics, Resistor, Ohm Law, electrical circuit and Capacitor.

2) Textbook Analysis

Analysis of textbooks conducted aims to see whether the contents of the book is in accordance with the competencies in the syllabus. Textbooks analyzed are textbooks that have been used in Basic Elektronika lectures. Based on the analysis that has been done, the results obtained that the students difficult to understand the book is due to the presentation of the book is not systematic in accordance with the syllabus given by the lecturer.

3) Literature Analysis

Activity analyzing the literature is an activity undertaken to collect materials related to module design. The characteristic structure of a module is important in designing.

4) Analysis of Student Characteristics

According to Kemp (1994: 61) at the beginning of planning is very important to pay attention to the characteristics, abilities and experience of students either in groups or individuals. In order for the module to be developed according to the needs of the students, the researcher learns the characteristics of the student by doing the observation.

Based on the results of observations and data collection that has been done, it is known that students of Bung Hatta University Informatics and Computer Education Study Program has a different background of high school. It is known that in the Academic Year 2015/2016 the percentage of students coming from science studies is $61 \%$ and social studies as much as $2 \%$. The background of high school students will of course affect the early ability, learning and motivation of students in Basic Elementary lectures. Textbooks used so far have not been able to become a learning resource that facilitates students with different high school backgrounds.

Based on the results of observations that have been done in lecturing process so far, it is known that the outline characteristics of student learning methods in Basic Elektronika lectures are as follows. a) The student easily forgets the concept he or she is learning if the student is not involved in the process of building an understanding of concepts such as making inventions. Learning resources used so far have not been able to involve students actively.

b) Students have difficulty learning independently with limited learning resources.

c) Students who listen and respond and can solve related problems and Practicum with material given by lecturers are students with high academic ability.
The results of the analysis of the characteristics of students at the University of Bung Hatta can be behind the need to develop a module. Module development can facilitate students to be involved in making discoveries of learned concepts so that what they learn is not easily forgotten. This certainly can lead to the emergence of student independence in learning.

\section{1) Interview with Friends}

After analyzing the Basic Electronics reference book, the next activity is an interview with colleagues. Interviews with colleagues aim to identify any problems / obstacles encountered in the field with respect to basic lectures in electronics. Interviews were conducted with lecturers of basic electronics courses, exploring information about obstacles and learning problems in the classroom.

Based on the results of interviews, it is known that during this basic lecture electronics course only refers to a textbook and using the lecture method. Many students rely on the explanation of the lecturer in understanding the material. This means, students have not been able to learn independently. Therefore, it takes a practical teaching materials from lecturers with certain development methods so as to facilitate students to learn independently. Thus, students do not need much help from lecturers in lectures.

\subsection{Designing}

The results at the defining stage are used as the basis at the design stage. At this stage the researchers designed modules on basic lectures electronics. This module is designed so that students are actively involved in making discoveries of the concepts they are learning. Research on learning media (Syahmaidi \& Hidayat, 2016, Syahmaidi, 2017a, 2017b; Hidayat, 2017), especially the learning module has been done (Syahmaidi, 2017c; Yulastri et al, 2017) and impact on learning outcomes and improving the quality of learning in education vocation (Kusumaningrum et al, 2015; Ganefri, 2015; Kusumaningrum et al., 2016; Hidayat, 2017; Ganefri et al., 2017).

Based on the analyzes performed at the defining stage, a module for electronics subject is designed. The following described the characteristics of the module designed.

\section{1) Cover Module}

Cover is designed with a black background that matches the color of the contents of the moduk. According to Seta (2009) red color can provide calm and increase concentration and can inspire. In the 
background cover there are some basic concepts of electronics written in white with different sizes. This is done so that students have a little picture about this course by looking at the cover. The title contained on the cover is "Elektronika Basic Module". This title provides the identity of the designed module. Title on cover using Times New Roman size 28 and Arial size 36 . Here is an example of presentation of cover.

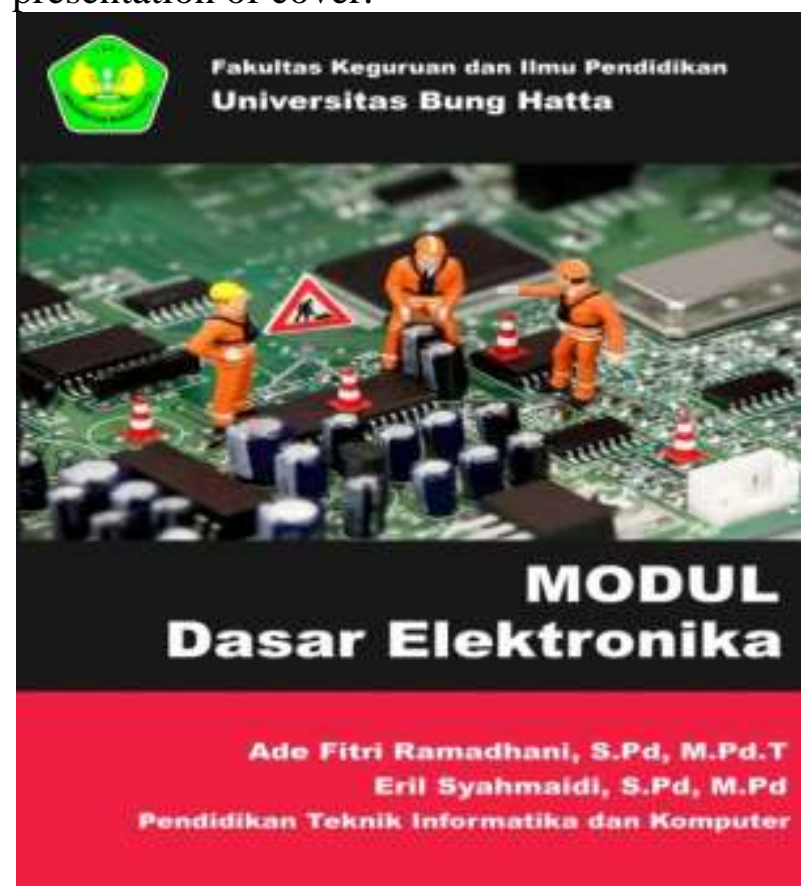

Figure 1: Cover the learning module

\section{1) Preface}

The preface contains about thanksgiving and the author's purpose of designing the module. Preface is made with words that are not formal and easy to understand students. The title of the preface uses Times Neew Roman letter size 22 and the words in the preface use the same letter with size 12 .

2) Table of Contents

Table of contents is made clearly so that students easily find the position / page of the desired material. The word table of contents uses Times New Roman letters size 22 and typing from the table of contents using the same letter with size 12 .

3) Material

The material in this module is developed with the purpose of learning so that students better understand the purpose of the material to be discussed. Here is a snippet of learning goals given to students.

\section{4) Sample Problem}

In the example problem there are questions that are relevant to the material presented. Examples of questions are presented in an easy-to-understand language with multiple-choice forms so as to facilitate students to learn independently.

\section{5) References}

The bibliography is at the end of the module. The bibliography contains references used at the time of writing the module. The bibliography is useful for informing the students from where the source of the Module is obtained.

\subsection{Development (develop)}

\section{a. Validation Stage}

The modules that have been designed are further validated by the validator. Validation Module is done by 2 validators. The module is valid after several discussions and fixes. The first validation activity was conducted by the Elementary Electronic course experts and language experts. The summary of the discussion with the validator can be seen in Table 2

Table 2: Summary of Validator Suggestions

\begin{tabular}{|c|c|c|}
\hline No & Validator & Suggestion \\
\hline 1 & Validator 1 & $\begin{array}{l}\text { 1) The naming / identity of the } \\
\text { image must be clear. } \\
\text { 2) presentation of the concept } \\
\text { should be able to invite } \\
\text { students to make the } \\
\text { discovery. } \\
\text { 3) Check again typing } \\
\text { sentences in the Module! } \\
\text { 4) The format of writing needs } \\
\text { to be improved. } \\
\text { 5) Cover customize with } \\
\text { module theme }\end{array}$ \\
\hline 2 & Validator 2 & $\begin{array}{l}\text { 1) Check again typing, } \\
\text { 2) The writing of inconsistent } \\
\text { image identity, } \\
\text { 3) Add a sample problem }\end{array}$ \\
\hline
\end{tabular}

Improvements made are tailored to the advice given from the validator. Further validation activities are performed at different times (adjusted to the willingness of the validator). This activity is conducted to discuss with the validator about the improvements that have been made. Discussions with validators related to the improvements made have resulted that the module has been valid and can be used in the trial.

Questionnaire data validator assessment results are described and analyzed qualitatively and quantitatively. Here is described the validation results Module that has been designed.

a) Material Aspects in the Module

The validation results of the material aspects in the Module can be seen in Table 3. In Table 3 it can 
be seen that the average validator's evaluation of modules designed is $>3.20$. According Muliyardi (2006: 82) if the average validation results worth> 3.20 then the basic module elektonika categorized very valid. Module validation results illustrate that the material presented is in accordance with the competence to be achieved. The material has been formulated based on the steps of making the module so as to provide an opportunity for students to find their own concept learned. This is supported by the systematic presentation of the material and the presence of examples of questions relevant to the material presented.

Table 3: Results of Material Aspect Validation in Modules

\begin{tabular}{lcccc}
\hline No & The aspect is & \multicolumn{2}{c}{ Validator } & Category \\
\cline { 3 - 5 } & validated & 1 & 2 & \\
\hline
\end{tabular}

\begin{tabular}{|c|c|c|c|c|}
\hline 1. & $\begin{array}{l}\text { The material } \\
\text { presented has been } \\
\text { in accordance with } \\
\text { the competence to } \\
\text { be achieved }\end{array}$ & 5 & 3 & Valid \\
\hline 2. & $\begin{array}{l}\text { The concepts } \\
\text { described in the } \\
\text { material are } \\
\text { affirmed with } \\
\text { graphs, tables, or } \\
\text { drawings }\end{array}$ & 5 & 4 & Valid \\
\hline 3. & $\begin{array}{l}\text { Presentation of the } \\
\text { material has } \\
\text { provided an } \\
\text { opportunity for } \\
\text { students to find } \\
\text { their own concepts } \\
\text { and principles } \\
\text { learned }\end{array}$ & 5 & 4 & Valid \\
\hline 4. & $\begin{array}{l}\text { Material has been } \\
\text { presented in a } \\
\text { systematic order }\end{array}$ & 5 & 4 & Valid \\
\hline 5. & $\begin{array}{l}\text { The material has } \\
\text { been formulated } \\
\text { based on the steps } \\
\text { of module creation }\end{array}$ & 5 & 4 & Valid \\
\hline 6. & $\begin{array}{l}\text { Examples of } \\
\text { questions, guided } \\
\text { exercises and } \\
\text { independent } \\
\text { exercises relevant } \\
\text { to the material } \\
\text { presented. }\end{array}$ & 5 & 4 & Valid \\
\hline
\end{tabular}

a) Presentation Aspects of the Module
The result of validation of presentation aspect in Module can be seen in Table 4 below.

Table 4: Results of Presentation Aspect Validation in Module

\begin{tabular}{lccc}
\hline No & $\begin{array}{c}\text { The aspect is } \\
\text { validated }\end{array}$ & \multicolumn{2}{c}{ Validator } \\
\cline { 3 - 4 } & 1 & 2 & Category
\end{tabular}

\begin{tabular}{|c|c|c|c|c|}
\hline 1. & $\begin{array}{l}\text { Key and specific } \\
\text { competencies and } \\
\text { module instructions } \\
\text { have been clearly } \\
\text { presented }\end{array}$ & 5 & 3 & Valid \\
\hline
\end{tabular}

In writing the

concept and term

2. formula that exist in $5 \quad 4 \quad$ Valid

the module has been

presented clearly

The presentation of

3. the material has $\begin{array}{llll}\text { conveyed the idea to } & 5 & 5 & \text { Valid }\end{array}$

be conveyed

The presentation of

the material has

4. $\begin{aligned} & \text { given rise to the } \\ & \text { process of concept }\end{aligned} \quad 5 \quad 4 \quad$ Valid

formation and

understanding

The presentation of

the material has

$\begin{array}{llll}\text { 5. } & \text { involved students } \\ \text { actively discovering } & 5 & 4 & \text { Valid }\end{array}$

the concept

independently

Presentation of clear

6. images with varying $5 \quad 4 \quad$ Valid

colors

the module has

presented the

7. formulation of issues $5 \quad 3 \quad$ Valid

for students in

making inventions

In Table 4 it can be seen that the average validator's evaluation of the designed module is $>$ 3.20. According Muliyardi (2006: 82) when the average validation results worth> 3.20 then the learning device is categorized very valid. Module's validation results illustrate that the Module elements such as key competencies, special competencies and usage instructions are clearly stated. The presentation of the material has involved students actively to find the concept independently. In 
addition, the presentation of the image is clear with varying colors.

a) Aspects of language and readability in the Module

The result of validation of language aspect and readability in Module can be seen in Table 5 below.

Table 5: Aspects of Language and Readability in Modules

\begin{tabular}{lllll}
\hline $\mathrm{N}$ & The aspect is & \multicolumn{2}{c}{ Validator } & \\
\cline { 3 - 4 } & validated & 1 & 2 & Category \\
\hline
\end{tabular}

\begin{tabular}{lllll}
\hline Sentences used are in & & & \\
1. $\begin{array}{l}\text { accordance with the } \\
\text { rules of the Indonesian } \\
\text { language }\end{array}$ & 4 & 3 & Valid \\
\hline $\begin{array}{l}\text { The sentence used } \\
\text { involves students' } \\
\text { logical thinking ability }\end{array}$ & 5 & 3 & Valid \\
\hline
\end{tabular}

The structure of the

3. sentence corresponds

to the level of student $\quad 5 \quad 4 \quad$ Valid

understanding

The shape and size of

the letters in the

4. $\begin{aligned} & \text { Module have been in } \\ & \text { accordance with the }\end{aligned}$
legibility of the
students

The sentence used in

the presentation of the

5. Module does not give a double meaning

(ambiguous)

In Table 5 it can be seen that the average validator's evaluation of module designed is $>3.20$. According Muliyardi (2006: 82) when the average validation results worth> 3.20 then the learning device is categorized very valid. Validation results illustrate that the use of sentences in the Module has been in accordance with the rules of good Indonesian language. Sentences used to involve students 'logical thinking ability because it has been adapted to the level of understanding and readability of students' capacity. This is supported by the presentation of a Module that does not give a double meaning.

Module validation results as a whole show that Module is very valid. During validation, the validator provides some suggestions contained in the validation sheet, including the following.
1. Giving a name / identity to the image must be clear.

2. presentation of the concept should be able to invite students to make the discovery.

3. Check again typing sentences in the Module!

4. The format of writing needs to be improved.

5. Cover customize with module theme

6. Check again typing,

7. The writing of the image identity is inconsistent,

8. Add sample questions.

Based on the suggestions provided by the validator, the researcher has revised the Module until the Module can be said to be very valid

\section{Conclusion}

Module for lecturing Elektronika is a lecture material of Bung Hatta Vocational High School students who can be used for lectures one semester. The module consists of 4 parts: Module 1 with subject matter Basic concept of electronics, Module 2 with subject of Resistor, Module 3 with subject of Electrical Circuit and Module 4 with Capacitor subject. Modules are developed through the defining (define), the design stage and the development stage. Validity Learning modules have been assessed by validators who are experts in the field of science, including the design of learning modules of videobased computer network system and language and literature that has been experienced in learning. So that the learning module of this computer networking system has met the valid criteria.

\section{References}

1. Bloom, Benjamin S. (1964). Taxonomy Of Educational Objectives. Amerika: Longmans

2. Dimyati dan Mudjiono. (2006). Learning and Learning. Jakarta: PT. Rineka Cipta-Ind

3. Ganefri., Hidayat, H. Production based Learning: An Instructional Design Model in the Context of Vocational Education and Training (VET). Procedia-Social and Behavioral Sciences, $204 \quad$ (2015): 206-211. https://doi.org/10.1016/j.sbspro.2015.08.142

4. Ganefri., Hidayat, H., Kusumaningrum, I., \& Mardin, A. (2017). Needs Analysis of Entrepreneurships Pedagogy of Technology and Vocational Education with Production Base Learning Approach in Higher Education. International Journal on Advanced Science, Engineering and Information Technology, 7(5), 1701-1707.

http://dx.doi.org/10.18517/ijaseit.7.5.1510 
5. Hamalik, Oemar. (2008). Teaching and learning process. Bandung: Bumi Aksara-Ind.

6. Hidayat, H. (2017). How is the Application and Design of a Product-Based Entrepreneurship Learning Tools in Vocational Higher Education?. Advances in Social Science, Education and Humanities Research, volume 102, 223-228. http://dx.doi.org/10.2991/ictvt17.2017 .38

7. Hidayat, H. (2017). Impact of Learning with the Production-Based Learning Model in Vocational School. International Journal of Research in Engineering and Social Sciences, 7(2), 1-6. http://indusedu.org/pdfs/IJRESS/IJRESS_1057_ 92032.pdf

8. Kemp, Jerrol. (1994). Teaching Design Process. Bandung: ITB Bandung-Ind

9. Kusumaningrum, I., \& Ganefri \& Hidayat, H. (2015). Improving Students' Entrepreneurial Interest using Production Based Learning Model in TVET. Advances in Social Science, Education and Humanities Research, 14, 69-74. http://dx.doi.org/10.2991/ictvet-14.2015.17

10.Kusumaningrum, I., Hidayat, H., Ganefri, , Anori, S. \& Dewy, M.S. (2016). Learning Outcomes in Vocational Education: a Business Plan Development by Production-Based Learning Model Approach. International Journal of Environmental and Science Education, 11(18), 11917-11930.

11.Lufri. (2007). Tips Understanding Methodology and Conducting Research. Padang: UNP PressInd.

12.Muliyardi. (2006). Development of Mathematical Learning Model Using Comics in First Class of Elementary School. Disertasi tidak diterbitkan. Surabaya : Pasca Sarjana UNESA-Ind.

13.Pribadi, Benny A. (2010). Important Steps of Designing Effective and Qualified Learning Activities Learning System Design Model. Jakarta: Dian Rakyat-Ind

14. Riduwan. (2005). Learn Easy Research for Beginning Teachers, Employees and Researchers. Bandung: Alfabeta-Ind.

15. Rosyid. (2010). Definition, Function, and Purpose of the Module. (http://www.rosyid.info/2010/06/pengertian- fungsi-dan-tujuan-penulisan.html, online March 2011) -Ind

16. Suharsimi, Arikunto. (2008). Fundamentals of Educational Evaluation. Jakarta: Bumi AksaraInd

17.Sugiyono. (2010). Educational Research Methods (Quantitative Approach, Qualitative and R \& D). Bandung: Alfabeta-Ind

18.Suherman, Erman. (2003). Common TextBook Strategi Pembelajaran Matematika Komtemporer. Bandung: JICA-Universitas Pendidikan Indonesia (UPI) -Ind

19.Suprawoto. (2009). Developing Teaching Materials by Creating Modules. http://www.Konstruktivisme/prinsip-

pembelajaran-konstruktivisme.html, diakses 8 Januari 2015) -Ind

20.Syahmaidi, E., \& Hidayat, H. (2016). Praktikalitas Perancangan Media e-Learning Berbasis Video. JURNAL NASIONAL PENDIDIKAN TEKNIK INFORMATIKA (JANAPATI), 5(2), 87-97.

21. Syahmaidi, E. (2017a). Pengembangan Media eLearning Mata Pelajaran Teknologi Informasi dan Komunikasi untuk Kelas XI SMA. Jurnal Ipteks Terapan, 9(1),88-97

22. Syahmaidi, E. (2017b). PERANCANGAN DAN PEMBUATAN MEDIA PEMBELAJARAN CD MULTIMEDIA INTERAKTIF UNTUK MATA PELAJARAN TEKNOLOGI INFORMASI DAN KOMUNIKASI KELAS $\mathrm{X}$ SMA. Edik Informatika, 1(2), 29-36.

23.Syahmaidi, E. (2017c). Pengembangan Modul Pembelajaran Perkuliahan Sistem Jaringan Komputer yang Valid pada Program Studi Pendidikan Teknik Informatika dan Komputer FKIP Universitas Bung Hatta. Jurnal EDik Informatika, 2(1), 25-35.

24. Trianto. (2007). Integrated Learning Model in Theory and Practice. Jakarta: Prestasi PustakaInd.

25. Yulastri, A., Hidayat, H., Ganefri, , Islami, S. \& Edya, F. (2017). Developing an Entrepreneurship Module by Using ProductBased Learning Approach in Vocational Education. International Journal of Environmental and Science Education, 12(5), 1097-1109. 